\title{
STUDIES OF HYALURONIC ACID IN RHEUMATOID
}

\section{ARTHRITIS}

\author{
BY
}

\author{
N. EGELIUS, E. JONSSON, AND L. SUNDBLAD \\ From the Medical Department III and the Central Laboratory, Södersjukhuset, Stockholm, Sweden
}

(RECEIVED FOR PUBLICATION JULY 4, 1956)

It has previously been shown that in most joint diseases changes occur in the hyaluronic acid in the joint fluid. In diseased fluids the hyaluronic acid has a considerably lower degree of polymerization than in normal fluids or in uncomplicated traumatic effusions (Sundblad, 1953).

The hyaluronic acid changes are especially marked in rheumatoid arthritis. We recently demonstrated (Sundblad, Egelius, and Jonsson, 1954) that the clinical response to the intra-articular injection of hydrocortisone is regularly accompanied by an often complete restoration to normal of the hyaluronic acid changes.

It appeared to us that determination of the degree of polymerization of the hyaluronic acid might provide a convenient objective record of the effects of therapy in joint diseases. The present study includes comparative tests with hydrocortisone acetate, hydrocortisone tertiary-butylacetate and other forms of local or systemic therapy. A brief discussion of the nature of the hyaluronic acid changes and their relation to certain clinical and laboratory data is also given.

\section{Methods}

Synovial Fluid.-Sterile samples were stored at $-20^{\circ} \mathrm{C}$. if not analysed immediately. After centrifugation the fluids were diluted with phosphate- $\mathrm{NaCl}$ buffer $(p \mathrm{H} \mathrm{7}$, ionic strength $0 \cdot 20$ ) before determination of viscosity.

Degree of Polymerization of Hyaluronic Acid.Hyaluronic acid is composed of units of $\mathrm{N}$-acetylglucosamine and glucuronic acid linked together to form highly polymerized molecules. Because of their molecular complexity, the solutions show a high viscosity even at small concentrations. Thus almost all of the viscosity of the synovial fluid is due to the hyaluronic acid. A further characteristic is the marked flow anomalies, in that pronounced alterations in the viscosity occur with changes of pressure. The so-called intrinsic viscosity (the ratio of viscosity to concentration in dilute solutions extrapolated to zero concentration) and the degree of anomalous viscosity are related to the average molecular size. They may be used as an index of the polymerization degree.

The anomalous viscosity test has been employed in the present investigation. This is more sensitive than the determination of the intrinsic viscosity and has the further advantage that no estimation of hyaluronic acid concentration is required. The method used has been previously described by Sundblad (1954). The anomalous viscosity (A) is directly calculated from two determinations of viscosity $N_{\mathrm{sp}}$ in the same capillary microviscometer, using two different pressures (maximum stresses of 7 and 17 dynes per $\mathrm{cm}^{2}$ ) as:

$$
A=\log \frac{\left(\mathbf{N}_{\mathrm{sp}}\right)_{7} \cdot\left[1+0 \cdot 16\left(\mathbf{N}_{\mathrm{sp}}\right)_{17}\right]}{\left(\mathbf{N}_{\mathrm{sp}}\right)_{17} \cdot\left[1+0 \cdot 16\left(\mathbf{N}_{\mathrm{sp}}\right)_{7}\right]}
$$

The values of $\frac{\mathbf{N}_{\mathrm{sp}}}{1+0 \cdot 16 \mathbf{N}_{\mathrm{sp}}}$ corresponding to the values

of $N_{s p}$ are conveniently taken from graphs. $N_{s p}$ is the specific viscosity of the hyaluronic acid. Corrections were thus made for protein viscosity, determined after complete degradation of the hyaluronic acid by incubating the samples with hyaluronidase. To avoid decimals the values of $A$ are given as $A \times 10^{3}$. In normal joint fluids the values for $A \times 10^{3}$ exceed 80 (Sundblad, 1953, 1954).

\section{Material}

Altogether about 500 samples of joint fluid were analysed by the method described. The majority of the patients from which the fluid samples were taken suffered from rheumatoid arthritis, the rest of them from various forms of other joint diseases. The present paper deals with the cases of rheumatoid arthritis and osteo-arthritis (about 400 samples of fluid from 134 cases). A few post-mortem fluids were also analysed. Most of the samples were obtained by knee puncture. In some cases several joints were examined in the same patient. 
TABLE I

RESPONSE TO DIFFERENT INTRA-ARTICULAR AGENTS OF THE ANOMALOUS VISCOSITY INDEX (A $\times 10^{3}$ ), 2 TO 3 DAYS AFTER INJECTION

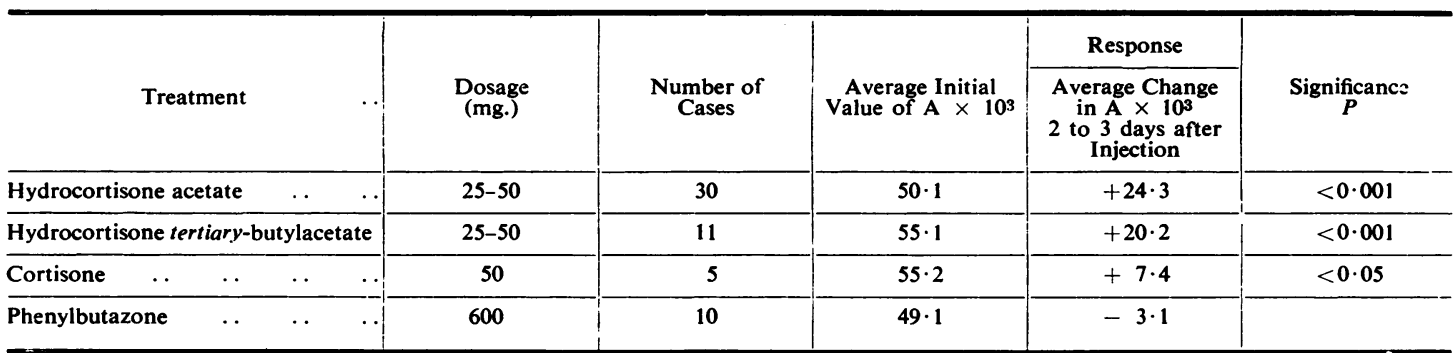

\section{Results}

(1) Intra-Articular Injections of Corticosteroids and Other Agents in Cases of Rheumatoid Arthritis.We previously showed (Sundblad and others, 1954) that the effect on the hyaluronic acid of intraarticular hydrocortisone is at its peak 2 to 3 days after injection. In Table I we have compared different agents with respect to the initial effect.

Table I shows that only agents with clinically proved local effect influence the hyaluronic acid. Treatment with hydrocortisone preparations was followed by increased values of anomalous viscosity in all cases, although the variation was comparatively great. In half the cases the values had returned to roughly normal after 2 to 3 days. Further analysis of the cases treated with hydro-? cortisone did not indicate any difference in bio- $\vec{G}$ chemical response to injections of 25 or $50 \mathrm{mg}$. The average increase in fourteen cases given $25 \mathrm{mg}$. was 26.2 as compared with 22.5 in 27 cases given $50 \mathrm{mg}$.

Duration of Effect.-In Fig. 1 the effect of hydrocortisone acetate is compared with that of hydrocortisone tertiary-butylacetate. In a preliminary publication (Egelius, Jonsson, and Sundblad, 1955) we stated that the average duration with hydrocortisone tertiary-butylacetate appeared to be longê than with hydrocortisone acetate. These resuls

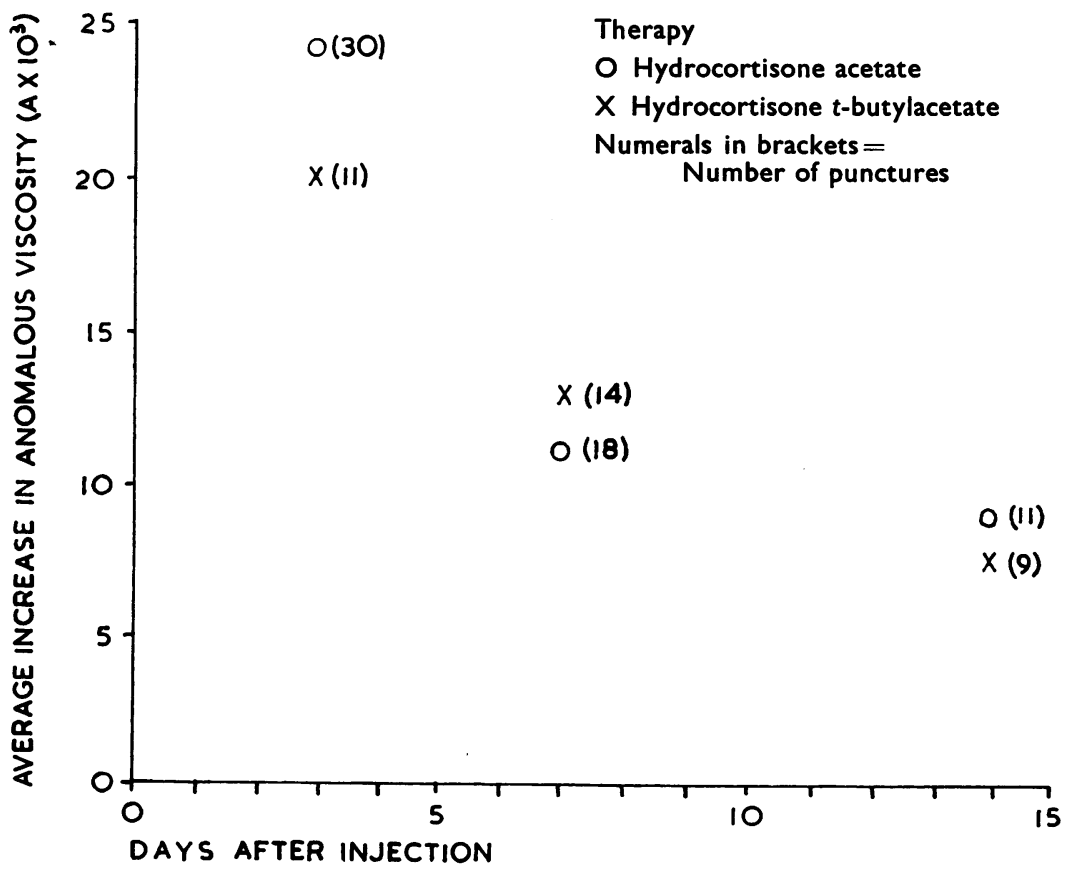

Fig. 1.-Average increase in anomalous viscosity of the synovial fluid in two series of patients with rheumatoid arthritis. Thirty were given hydrocortisone acetate and fourteen were given 3 hydrocortisone tertiary-butylacetate. The number of fluids tested after 3,7 , and 14 days are shown in brackets. 
agreed with the clinical observations made by Hollander, Brown, Jessar, and Brown (1954). However, no significant difference was found between the two preparations.

In certain cases efforts were made to increase the initial effect and the duration by the repeated administration of hydrocortisone acetate at intervals of from 1 to 2 days, but nothing appeared to be gained by this procedure. In three cases $600 \mathrm{mg}$. phenylbutazone was given every second day four to six times without any clinical or biochemical effect. On the contrary, in some cases we noted a significant drop in the anomalous viscosity values after intraarticular phenylbutazone injections. Probably this is due to a chemical synovitis, clinically demonstrated in these cases by increase in pain and exudation.

Action of Hydrocortisone on Hyaluronidase.It has been shown by Ekman, Thune, and Truedsson (1953) that, after repeated intra-articular injections of cortisone, there is an increase in the hyaluronidase

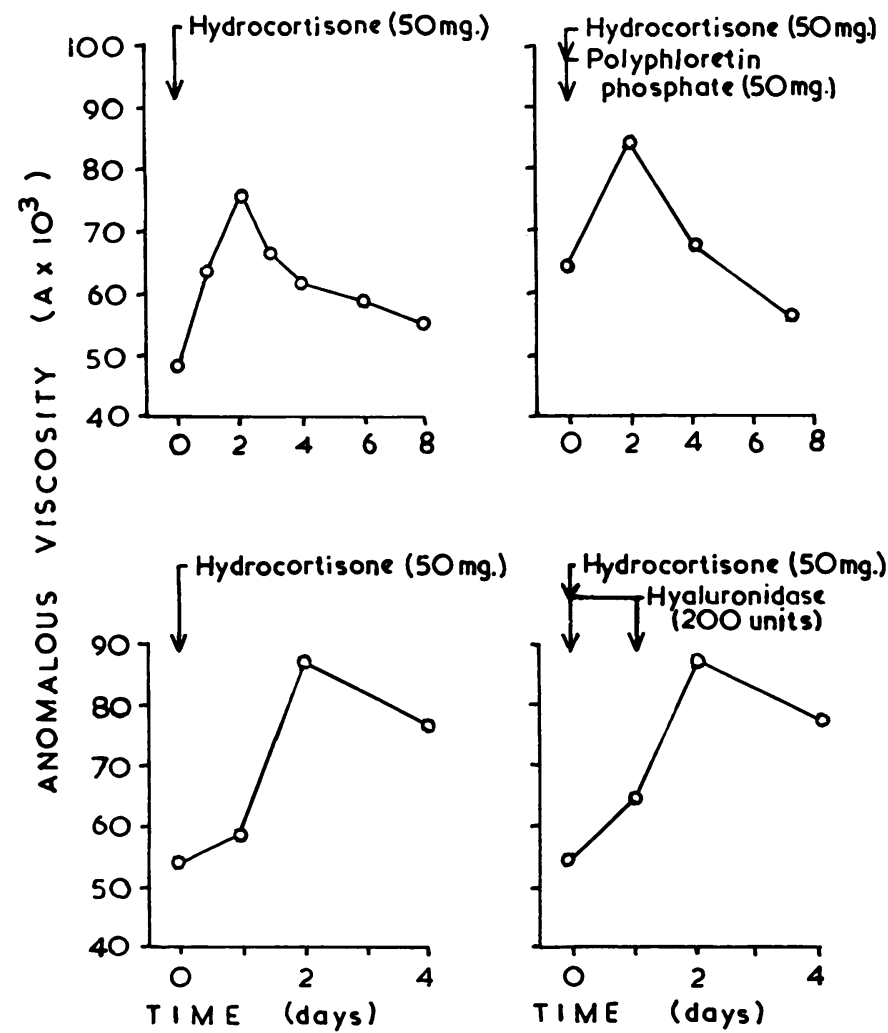

Fig. 2.-Anomalous viscosity levels in two female patients (A and $B$ ) after the injection of hydrocortisone, hyaluronidase, and hyaluronidase inhibitor. In each experiment the initial increase was followed by a steady fall. inhibitor level in the joint fluid. Furthermore, Hahn, Thune, and Truedsson (1952) claimed to have shown a therapeutic effect of hyaluronidase inhibitor therapy in rheumatoid arthritis. On the other hand, the serum inhibitor level is known to decrease after ACTH therapy.

We have made a series of experiments to study the possible relationship between the local action of hydrocortisone and hyaluronidase or antihyaluronidase factors. As previously reported, we demonstrated a decrease in hyaluronidase inhibitor activity in the joint fluids 2 days after hydrocortisone administration. Intra-articular injections of high doses of a potent hyaluronidase inhibitor (polyphloretin phosphate*) did further not influence the hyaluronic acid conditions (Sundblad and others, 1954).

In two patients, the administration of hyaluronidase or hyaluronidase inhibitor together with hydrocortisone did not appear to influence the response to the hormone (Fig. 2), and it seemed unlikely that the action of hydrocortisone on the hyaluronic acid was mediated by any influence on the hyaluronidase factors.

A few experiments of theoretical interest in this connexion may be briefly mentioned. An antagonism between vitamin $\mathrm{B}_{12}$ and hydrocortisone upon carbohydrate metabolism has been supposed by Lövgren, Norman, and Winqvist (1955). In a case of rheumatoid arthritis with bilateral knee-joint effusions, we injected into one knee $25 \mathrm{mg}$. hydrocortisone and $25 \mu \mathrm{g}$. vitamin $\mathbf{B}_{12}$ and into the other knee hydrocortisone only. The change in anomalous viscosity obtained after 2 days was the same in both knees.

Boström, Rodén, and Vestermark (1955) have shown that glutamine may play an important role in the biosynthesis of the mucopolysaccharides. In view of this we recently started some experiments with the intra-articular administration of glutamine. So far no significant effect upon the hyaluronic acid has been noted.

(2) Systemic Therapy.-The hyaluronic acid changes were observed in three cases of rheumatoid arthritis treated with oral hydrocortisone (maximum dosage $80 \mathrm{mg}$. daily). All three patients showed a comparatively slight clinical response

\footnotetext{
* Leo Ltd.
} 

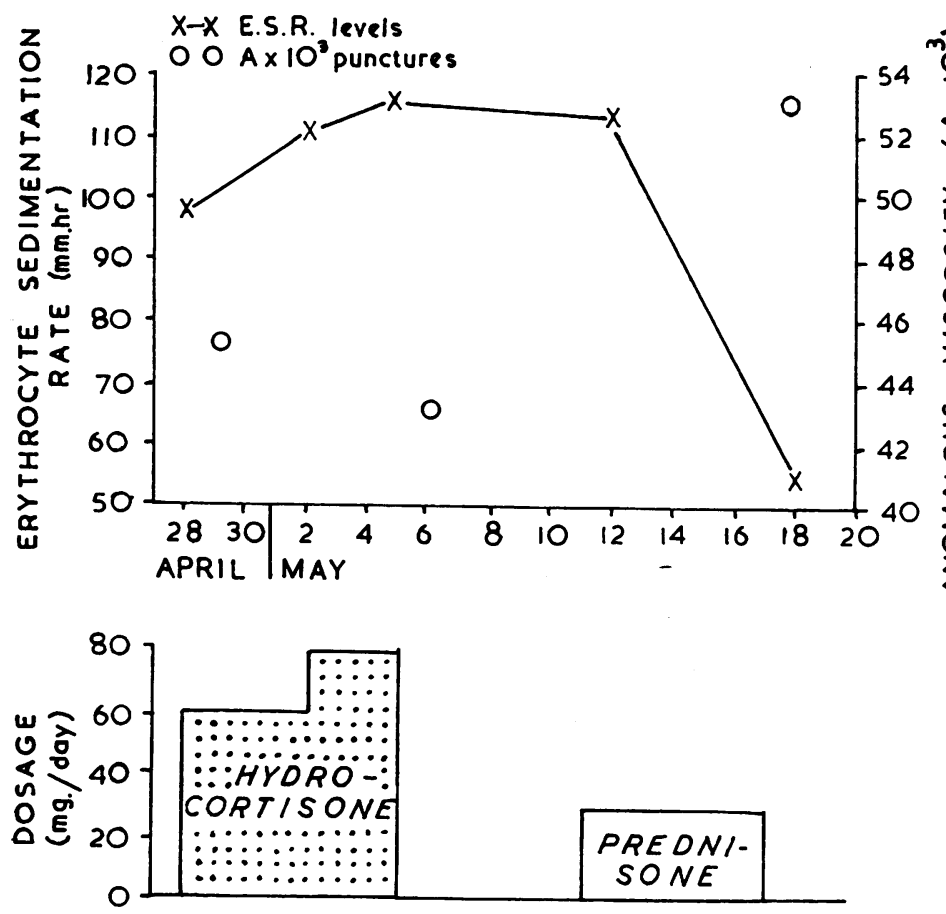

Fig. 3.-Anomalous viscosity level and erythrocyte sedimentation rate in a female aged 59 with rheumatoid arthritis treated with hydrocortisone and prednisone.
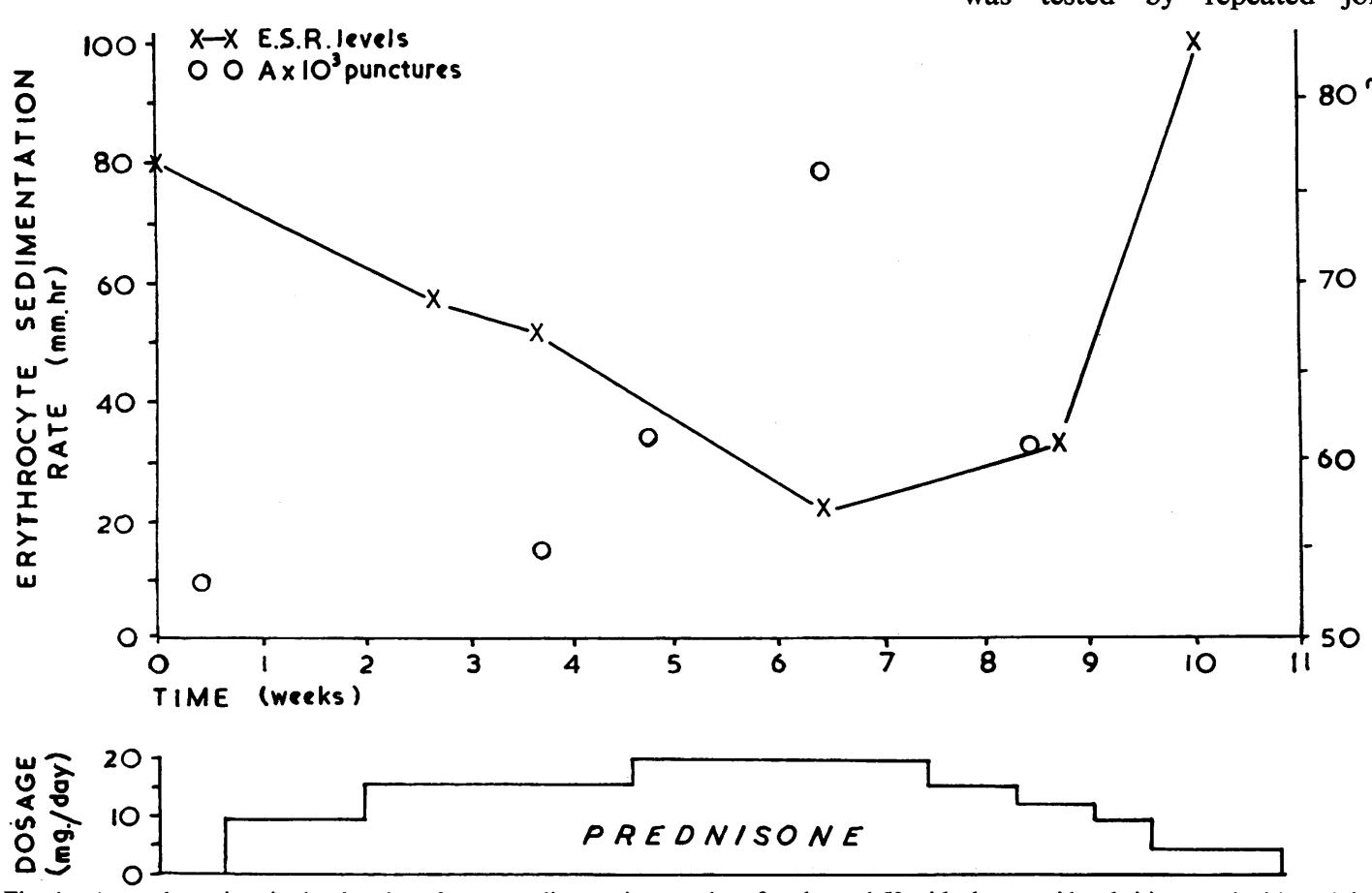

Fig. 4.-Anomalous viscosity level and erythrocyte sedimentation rate in a female aged 53 with rheumatoid arthritis treated with prednisone. with only moderate changes in the erythrocyte sedimentation rate. The change in anomalous viscosity $\frac{0}{\omega}$ was slight (average initial value A $\times 10^{3}=50 \cdot 5 ;$ average change $\stackrel{5}{\rightarrow}$ $+4 \cdot 5)$. In one of these cases we 0 exchanged the hydrocortisone for $\frac{\bar{\sigma}}{\bar{F}}$ prednisone $30 \mathrm{mg}$. daily, and the $\frac{\bar{s}}{\partial}$ anomalous viscosity values in- $\stackrel{\mathbb{D}}{\varrho}$ creased by 23 per cent. (Fig. 3), ڤँ and the clinical effects were also $\rightarrow$ satisfactory. Good effects with 0 $20 \mathrm{mg}$. prednisone daily were also $\overrightarrow{\vec{\omega}}$ obtained in another case which $\stackrel{\sigma}{\mathscr{D}}$ showed a maximum increase of $\frac{m}{2}$ 43 per cent. (Fig. 4).

In three cases treated with 5-6 $\vec{G}$ g. salicylic acid daily, only very slight changes in anomalous vis- of cosity were noted (average initial 응

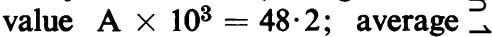
change $-1 \cdot 2$ ).

(3) Miscellaneous. - In eight cases the effect of various forms of physiotherapy (short wave dia- $\mathbb{\mathbb { D }}$ thermy four cases, radar twg $\overrightarrow{\vec{\theta}}$ cases, and hot mud two caseg of was tested by repeated joir

$$
\frac{10}{2}
$$


punctures. In no case was any significant change in the anomalous viscosity noted (average initial value $45 \cdot 9$; average change $+1 \cdot 7$ ).

Finally we examined three cases treated with $x$-ray therapy. In one we noted a significant and lasting increase in anomalous viscosity, but this should probably be ascribed to a spontaneous remission of the disease.

(4) Nature of Hyaluronic Acid Changes.-The clinical and laboratory data of 119 cases of rheumatoid arthritis were analysed by the following criteria:

(a) Sex and age,

(b) Type of onset according to the classification of Egelius, Hävermark, and Jonsson (1949),

(c) Stage of disease according to the classification of Steinbrocker, Traeger, and Batterman (1949),

(d) Evidence of bone destruction,

(e) Erythrocyte sedimentation rate,

(f) Haemoglobin value,

(g) C-reactive protein in blood and joint fluid,

(h) Sensitized sheep-cell agglutination test,

(i) Streptococcal agglutination and antistreptolysin titres.

There were no significant correlations between these data and the hyaluronic acid changes, but the viscosity values tended to be lower in early cases, in cases without bone destruction, and in younger patients.

Since the presence of osteo-arthritis in older patients might have influenced the results, we analysed fifteen fluids from cases of osteo-arthritis. The average of A $\times 10^{3}$ was 53.5 as compared with 51.4 in the 119 cases of rheumatoid arthritis. Thus there was no essential difference between these two conditions $(d=2 \cdot 1$; $t=0.58 ; P>0.1)$. Similar results have been reported by Sundblad (1953) in determinations of intrinsic viscosity, and more recently by Fletcher, Jacobs, and Markham (1955) in the anomalous viscosity test.

No correlation was found between the hyaluronic acid changes and the activity of the disease as judged by conventional criteria. This did not support the idea of a general type of hyaluronic acid disturbance. On the other hand fluids obtained from both knees in cases with bilateral knee joint effusions were often remarkably similar with respect to hyaluronic acid changes.

To examine the problem further we compared the anomalous viscosity indices of affected and unaffected joints in four patients with rheumatoid arthritis (postmortem puncture in one case; amounts of fluid in the affected joints not measurable in another). The results are shown in Table II, and are also compared with the indices of fluids taken from normal persons (not affected by joint disease) obtained by punctures performed as soon as possible post-mortem. We were not inclined to perform in vivo punctures on healthy persons.

The results given in Table II show that in the cases of rheumatoid arthritis the degree of hyaluronic acid changes differed widely between the affected and unaffected joints, but that in different joints in the control cases it was essentially the same. From the data of intrinsic viscosity in normal joint fluids given by Sundblad (1953) and the correlation between anomalous viscosity and intrinsic viscosity (Sundblad, 1954), a probable range of values of $A \times 10^{3}$ in normal human fluid would be 80 to 100 . This agrees with the findings in the postmortem fluids in Table II. In spite of the small number of cases it seems justified to conclude that in clinically normal joints in rheumatoid arthritis the hyaluronic acid has a normal degree of polymerization. Accordingly the hyaluronic acid changes in affected joints must be due to local connective tissue disturbance.

TABLE II

COMPARISON OF THE ANOMALOUS VISCOSITY INDICES $\left(A \times 10^{3}\right)$ IN THE AFFECTED AND CLINICALLY NORMAL JOINTS OF FOUR PATIENTS WITH RHEUMATOID ARTHRITIS AND IN SELECTED JOINTS OF FOUR CONTROLS

\begin{tabular}{|c|c|c|c|c|c|c|c|c|c|c|c|}
\hline Case No. & \multirow[b]{2}{*}{$1^{*}$} & \multirow{2}{*}{$\frac{\text { Sex }}{\mathbf{M}}$} & \multirow{2}{*}{$\begin{array}{c}\begin{array}{c}\text { Age } \\
\text { (yrs) }\end{array} \\
39\end{array}$} & $\begin{array}{c}\text { Clinical } \\
\text { Findings }\end{array}$ & \multirow{2}{*}{$\frac{\begin{array}{c}\text { Typical } \\
x \text { ray }\end{array}}{\text { Yes }}$} & \multirow{2}{*}{$\frac{\begin{array}{c}\text { Stage of } \\
\text { Disease }\end{array}}{\text { II }}$} & \multirow{2}{*}{$\frac{\begin{array}{c}\text { E.S.R. } \\
(\mathrm{mm} . / \mathrm{hr})\end{array}}{123}$} & \multirow{2}{*}{$\begin{array}{l}\begin{array}{c}\text { Unaffected } \\
\text { Joints }\end{array} \\
\begin{array}{l}\text { R. knee } \\
\text { R. hip }\end{array}\end{array}$} & \multirow{2}{*}{$\begin{array}{c}A \times 10^{3} \\
85 \cdot 1 \\
73 \cdot 6\end{array}$} & \multirow{2}{*}{$\begin{array}{c}\begin{array}{c}\text { Affected } \\
\text { Joints }\end{array} \\
\text { L. knee }\end{array}$} & \multirow{2}{*}{$\frac{A \times 10^{3}}{10 \cdot 6}$} \\
\hline \multirow{4}{*}{$\begin{array}{c}\text { Rheumatoid } \\
\text { Arthritis }\end{array}$} & & & & $\begin{array}{l}\text { Iritis. Death } \\
\text { in uraemia } \\
\text { due to } \\
\text { amyloidosis }\end{array}$ & & & & & & & \\
\hline & 2 & $\mathbf{M}$ & 61 & $\begin{array}{c}\text { Waaler-Rose } \\
1 / 160\end{array}$ & Yes & III & 56 & L. knee & $83 \cdot 9$ & $\begin{array}{l}\text { L. wrist } \\
\text { L. ankle }\end{array}$ & $\begin{array}{l}\text { too low to } \\
\text { measure }\end{array}$ \\
\hline & 3 & $\mathbf{F}$ & 45 & - & Yes & III & 19 & R. knee & $93 \cdot 6$ & L. $2 \mathrm{mcp}$ & 51 \\
\hline & 4 & $\mathbf{F}$ & 48 & $\begin{array}{c}\text { Waaler-Rose } \\
1 / 40\end{array}$ & No & II & 30 & L. knee & $82 \cdot 6$ & R. knee & $48 \cdot 7$ \\
\hline \multirow{4}{*}{$\begin{array}{l}\text { Controls } \\
\text { (No Joint } \\
\text { Disease) }\end{array}$} & $5 *$ & $\mathbf{F}$ & 15 & \multicolumn{4}{|c|}{ Acute tracheo-bronchitis and pneumonia } & R. hip & 85 & & \\
\hline & $6^{*}$ & $\mathbf{M}$ & 35 & \multicolumn{4}{|c|}{ Myocardial infarction } & $\begin{array}{l}\text { R. hip } \\
\text { R. knee }\end{array}$ & $\begin{array}{l}84 \cdot 6 \\
88 \cdot 9\end{array}$ & & \\
\hline & $7 *$ & $\mathbf{M}$ & 74 & \multicolumn{4}{|c|}{ Bronchopneumonia and cardiosclerosis } & R. hip & $85 \cdot 2$ & & \\
\hline & $8^{*}$ & $\mathbf{M}$ & 50 & \multicolumn{4}{|c|}{$\begin{array}{l}\text { Congenital heart disease. } \\
\text { failure }\end{array}$} & $\begin{array}{l}\text { L. hip } \\
\text { R. knee }\end{array}$ & $\begin{array}{l}91 \cdot 7 \\
85 \cdot 9\end{array}$ & & \\
\hline
\end{tabular}

* Post-mortem punctures. 


\section{Summary}

Determination of the degree of polymerization of the synovial hyaluronic acid provides a convenient method of recording objectively the effects of treatment of rheumatoid arthritis. Hyaluronic acid changes can easily be estimated by determining the changes in viscosity of the synovial fluid. No determination of hyaluronic acid concentration is required.

Intra-articular administration of both hydrocortisone acetate and hydrocortisone tertiarybutylacetate restored the hyaluronic acid changes almost to normal within 2 to 4 days. After a single injection the average duration of effect was 2 to 3 weeks. In this respect no definite difference could be established between the two preparations. There was no obvious difference between the response to doses of $25 \mathrm{mg}$. and that to doses of $50 \mathrm{mg}$.

Intra-articular cortisone caused only a slight effect and phenylbutazone none at all.

No effect was obtained with physical therapy, $x$-ray therapy, or salicylates.

The systemic administration of hydrocortisone or prednisone produced variable effects which roughly paralleled the clinical response. Only a few cases were tested.

A series of experiments demonstrated that hydrocortisone does not appear to influence the hyaluronidase or anti-hyaluronidase factors. The effect of the hormone on the hyaluronic acid is probably due to anti-inflammatory action on the perisynovial connective tissue.

In a series of 119 cases of rheumatoid arthritis there was no significant correlation between the activity of disease and the degree of hyaluronic acid changes in the synovial fluid. In clinically normal joints the degree of polymerization of the hyaluronic acid was normal. These findings suggest that the hyaluronic acid changes in affected joints are unlikely to be due to a general disturbance of hyaluronic acid metabolism.

\section{REFERENCES}

Boström, H., Rodén, L., and Vestermark, A. (1955). Nature (Lond.), 176, 601 .

Egelius, N., Hävermark, N. G., and Jonsson, E. (1949). Annals of the Rheumatic Diseases, 8, 217.

- Jonsson, E., and Sundblad, L. (1955). "Proc. III European Rheumatology Congress."' In the press.

Ekman, B., Thune, S., and Truedsson, E. (1953). Scand. J. clin. Lab.' Invest., 5, 175.

Fletcher, E., Jacobs, J. H., and Markham, R. L. (1955). Clin. Sci., 14, 653 .

Hahn, L., Thune, S., and Truedsson, E. (1952). Annals of the Rheumatic Diseases, 11, 272.

Hollander, J. L., Brown, E. M., Jr., Jessar, R. A., and Brown, C. Y. (1951). J. Amer. med. Ass., 147, 1629.

Lövgren, O., Norman, A., and Winqvist, G. (1955). Acta rheum. scand., 1, 106.

Steinbrocker, O., Traeger, C. H., and Batterman, R. C. (1949). J. Amer. med. Ass., 140, 659.
Sundblad, L. (1953). Acta Soc. Med. upsalien., 58, 113. (1954). Scand. J. clin. Lab. Invest., 6, 288 -, Egelius, N., and Jonsson, E. (1954). Ibid., 6, 295.

\section{Etudes de l'acide hyaluronique dans} l'arthrite rhumatismale

\section{RÉSUMÉ}

La détermination du degré de polymérisation de l'acide hyaluronique synovial fournit une méthode pratique pour enrégistrer objectivement les effets du traitement de l'arthrite rhumatismale. Les altérations de l'acide hyaluronique peuvent être aisément estimées par la détermination des modifications de la viscosité du liquide synovial. La détermination du taux d'acide hyaluronique n'est pas nécessaire.

L'injection intra-articulaire aussi bien d'acétate de hydrocortisone que de butylacétate tertiaire d'hydrocortisone ramenait l'état de l'acide hyaluronique presqu'à la normale en l'espace de 2 à 4 jours. Après une seule injection, la durée moyenne de l'effet produit était de 2 à 3 semaines. De ce côté-ci on ne pouvait mettre en évidence aucune différence entre les deux préparations. Il n'y avait pas de différence marquée entre la réponse à des doses de $25 \mathrm{mg}$. et celle à des doses de $50 \mathrm{mg}$.

La cortisone intra-articulaire ne produisait qu'un effet léger et la phényl-butazone n'en produisait aucun.

Le traitement physique, aux rayons $X$ et salicylé, fut sans effet.

L'administration générale d'hydrocortisone ou de prednisone produisait des effets variables, plus ou moins parallèles à la réponse clinique. Seuls quelques cas furent étudiés.

Une série d'expériences montra que l'hydrocortisone ne semble pas influencer les facteurs hyaluronidase antihyaluronidase. L'effet de l'hormone sur l'acide hyaluronique est probablement dû à une action antiinflammatoire du tissu conjonctif périsynovial.

Dans une série de 119 cas d'arthrite rhumatismale, il n'y eut pas de corrélation significative entre l'activité de la maladie et l'importance des altérations de l'acide hyaluronique dans le liquide synovial. Dans les articulations cliniquement normales, le degré de polymérisation de l'acide hyaluronique était normal. Ces résultats suggèrent que les altérations de l'acide hyaluronique dans les articulations malades ne seraient pas dues à un dérangement général du métabolisme de l'acide hyaluronique.

\section{Estudios del ácido hialurónico en la artritis reumatoide}

\section{Sumario}

La determinación del grado de polimerización del ácido hialurónico sinovial provee un método práctico para registrar objetivamente los efectos del tratamiento de la artritis reumatoide. Las alteraciones del ácido hialurónico se pueden seguir fácilmente al determinar los cambios en la viscosidad del líquido sinovial. La determinación de las cifras del ácido hialurónico no es necesaria.

Inyecciones intra-articulares tanto de acetato de hidrocortisona como de butilacetato terciario de hidrocortisona restablecían el ácido hialurónico a su estado casi normal dentro de 2 a 4 días. Después de una sola inyección el efecto duraba por término medio de 2 a 3 semanas. En este respecto no se pudo evidenciar diferencia alguna entre las dos preparaciones. Tampoco 
hubo diferencia obvia entre el efecto de una dosis de $25 \mathrm{mg}$. y él de una dosis de $50 \mathrm{mg}$.

La cortisona intra-articular no produjo más que un efecto ligero; la fenilbutazona fué sin efecto.

Fisioterapia, radioterapia y salicilatos no tuvieron efecto alguno.

La administración general de hidrocortisona o de prednisona produjo efectos variables, más o menos paralelos a la respuesta clínica. Pocos casos fueron investogados.

Una serie de experimentos muestra que la hidrocortisona no parece influir en los factores hialuronidase y antihialuronidase. El efecto de la hormona sobre el ácido hialurónico se debe probablemente a una acción anti-inflamatoria del tejido conjuntivo perisinovial.

En una serie de 119 casos de artritis reumatoide, no hubo correlación significativa entre la actividad de la enfermedad y la importancia de las alteraciones del ácido hialurónico en el líquido sinovial. En articulaciones clínicamente normales, el grado de polimerización del ácido hialurónico fué normal. Estos resultados sugieren que las alteraciones del ácido hialurónico en las articulaciones enfermas no se deben a un desarreglo general del metabolismo del ácido hialurónico. 